\title{
Pierre Nicole, Jean-Baptiste Dubos, and the Psychological Experience of Theatrical Performance in Early Modern France
}

\author{
Logan J. Connors
}

1

\author{
Introduction: A History of Psychology, a History of Theatrical \\ Performance?
}

A seemingly off-topic question with which to begin an essay about early modern theories of theatrical performance: What did psychology-often defined as the scientific study of the human mind and its functions-look like before the nineteenth century? By employing words like 'scientific', 'mind', and 'function', this line of inquiry leads to plenty of confusion today, let alone when we examine earlier periods. As an interpreter of texts about literature, theatre, and other arts from the early modern period, I am often reminded of the difficulty we encounter in distinguishing so-called 'scientific study' from 'theological study' or from 'cultural studies'; sources and motives overlap and intertwine, making anything that might be called early modern psychology both tough to locate and confusingly ubiquitous.

Despite these difficulties, research into psychology avant la lettre has garnered more and more attention from a variety of disciplines, including psychology (though this is rare) and, more often, anthropology, philosophy, literary studies, religious studies, the history of science and medicine and, more recently, the history of emotions. Studies in these diverse fields ${ }^{1}$ can help

1 The bibliography is indeed vast; of special note for this essay are Fernando Vidal, Les Sciences de l'âme, XVI ${ }^{e}-X V I I I^{e}$ siècle (Paris: Honoré Champion, 2006); William M. Reddy, The Navigation of Feeling: A Framework for the History of Emotions (Cambridge: Cambridge University Press, 2001); Phyllis Mack, Heart Religion in the British Enlightenment: Gender and Emotion in Early Methodism (Cambridge: Cambridge University Press, 2008); Reading the Early Modern Passions: Essays in the Cultural History of Emotion, ed. by Gail Kern Paster, Katherine Rowe, and Mary Floyd-Wilson (Philadelphia: University of Pennsylvania Press, 2004); Les Émotions publiques et leurs langages à l'âge classique, ed. by Hélène Merlin-Kajman, Littératures classiques 68 (Paris: Honoré Champion, 2009); Thomas Dixon, From Passions to Emotions: The Creation of a Secular Psychological Category (Cambridge: Cambridge University Press, 2003); Anne Coudreuse, Le refus du pathos au XVIII e siècle (Paris: Honoré Champion, 2001). For a 
inform those of us who study early modern theatre, a field and experience that, like psychology, was and is a contested site of disparate discourses that compete to define and describe precisely its scope, disciplinary tools, and intellectual underpinnings.

The variety of ways to access the emotions during the early modern period is reflected in the different domains that are at present attempting to describe early psychology. For example, in Les sciences de l'âme, Fernando Vidal provides some of the most robust theorising on pre-psychology. He traces the advent of psychology from attacks on Aristotle during the Italian Renaissance to the formalisation of psychology as a discipline in Germany during the late eighteenth century. Vidal dedicates most of his study to this later period, arguing that 'eighteenth-century psychology absorbs the subjects of logic, metaphysics and moral philosophy, and emerges at the heart of anthropology, or the general science of man, an unprecedented domain' ('la psychologie du XVIII siècle absorbe des matières de la logique, de la métaphysique et de la morale, et se place au cœur d'un autre champ inédit, l'anthropologie ou science générale de l'homme'). ${ }^{2}$ Vidal, of course, is not alone in his quest to unearth theories of cognition, emotion, motivation, and other psychological notions that permeated a range of traditions during the early modern period and that would become objects of formal scientific analysis by the late nineteenth century.

In her work on sensibility, Jessica Riskin insists that by the time JeanBaptiste Lamarck published his Philosophie zoologique in 1809, France already possessed a rich theoretical corpus on psychology, or what might have been called the 'sentimental empiricism' that Denis Diderot, Etienne Bonnot de Condillac, the Baron d'Holbach, and others had developed and transformed throughout the second half of the eighteenth century. ${ }^{3}$ In his work on the physician-anatomist Pierre Jean George Cabanis, Sergio Moravia argues that Cabanis's 1796 claim that mental disorders were functions of brain abnormalities rather than symptoms of 'moral problems' was actually part of an effort to explain universal humankind, and that this claim constituted the result of over thirty years of materialist physiological research during the later $1700{ }^{4}{ }^{4}$

concise introduction to the history of emotions, see Jan Plamper, The History of Emotions: An Introduction (Oxford: Oxford University Press, 2015).

2 Vidal, p. 14. Unless otherwise noted, all translations are my own.

3 Jessica Riskin, Science in the Age of Sensibility: The Sentimental Empiricists of the French Enlightenment (Chicago: University of Chicago Press, 2002), p. 4.

4 Sergio Moravia, 'The Enlightenment and the Sciences of Man', History of Science, 18 (1980), p. 254 . 
Cabanis's desire to attach psychological causality to internal, biological processes was the natural conclusion of a researcher whose avowed interest was the science de l'homme - a wide- and far-reaching set of theories about the complex processes of human nature that sought to connect metaphysical, moral, or spiritual aspects of human life to the body, thereby wresting these issues from the hands of moralists and church leaders. In contrast to studies from the rationalist-scientific approach, Thomas Dixon, in From Passions to Emotions: The Creation of a Secular Psychological Category, has located many of the 'modern' emotions of the nineteenth century (many Jamesian constructs, for example) in religious writing (mostly in England) from the seventeenth and eighteenth centuries. ${ }^{5}$

What binds these disparate studies together is the notion that a field as interdisciplinary as psychology cannot trace its roots back to one domain or line of inquiry. The rich interdisciplinarity that undergirds both the sources at the time and the current analysis of the history of psychology (I just named a psychologist, a historian, a philosopher, and a scholar of religion, respectively) could serve as an analogy for the study of the history and conceptual development of how writers described theatrical performance-that 'kaleidoscopic adventure' which involves a complex network of people, places, things, and non-things. ${ }^{6}$

In what follows, I will move from the theoretical underpinnings of psychology - texts from the domains of metaphysics, theology, and anatomy - to the dissemination, the application, or even what might be called the vulgarisation of psychology through an examination of several discourses about the theatre performance and its psychological effects on spectators. The connections between these two histories and their vulgarisations - the history of the dissemination of psychological precepts and theories, and that of theatrical discourses and theories - are in fact surprising. I argue that early modern theatre served as a dynamic site to test and contest emerging psychological and psychosocial theories. Yet this was not a one-way street from philosophy to theatre or from anatomical reflection to dramatic criticism; the anti-theatrical and pro-theatrical writers in my corpus actually informed the history of philosophy - from their reinterpretations of Cartesian mechanics in regards to acting styles to their addition of nuance and complexity to an emerging sensationalist branch of epistemology.

It is important first to note, however, that the vulgarisation question is always tricky: scholars are quick to point out how ideas permeated society

5 For Dixon's thesis, see his From Passions to Emotions, pp. 2-24.

6 Edwin Wilson, The Theater Experience, 4th edn (New York: McGraw Hill, 1988), p. 2. 
(as, for example, does Robert Darnton in his works about the illegal book trade in France $)^{7}$ but hesitant to think about why complex scientific and religious doctrines found new avenues at specific moments into more public discursive arenas, such as theatre, painting, politics, and general polemics. As we shall see, some of France's most robust writing on consciousness and sensibility did not result from a murky 'dissemination of lumières' process - a spread of ideas for the sake of ideas. Instead, particular discourses about the human psyche and about theatre appeared alongside specific political reasons and goals, such as justification for the survival and proliferation of state-sponsored theatres or for the annihilation of theatre and 'theatrical life' in the French kingdom.

The analysis of theatrical theories that follows is thus grounded in particular notions of the political and social missions of theatre in early modern France. While one of my overall objectives is indeed to show how 'theatre theory is $[\ldots]$ a reflection as much on fundamental issues of human nature and psychology as on dramatic practice, ${ }^{8}$ I also hope to prove that these 'fundamental issues' were constantly subject to revision and retooling. In sum, the histories of psychology and theatre overlap in that they both are subject to precise political anchoring. For example, the Fronde crisis (1648-1653) between nobles and the crown or the Regency (1715-1723) were specific contexts with particular cultural programs in the history of French politics-moments that influenced and undergirded any seemingly universal call to explain either theatre or the human psyche.

This essay is part of a larger project that attempts to show the conceptual birth —or, at the least, the theoretical strengthening — of what is often called the bourgeois spectator experience: an experience of individualised, mindful, and emotional attachment to staged fiction that dominated the explicit goals of dramatic literature and theatrical life throughout the second half of the eighteenth century, and that would only come to be criticised much later, during the late nineteenth and early twentieth centuries, by writers such

7 See Darnton's landmark work, The Literary Underground of the Old Regime (Cambridge: Harvard University Press, 1982), as well as The Forbidden Best-Sellers of Pre-Revolutionary France (New York: W.W. Norton \& Company, 1996); The Corpus of Clandestine Literature in France, 1769-1789 (New York: W.W. Norton \& Company, 1995); Poetry and the Police: Communication Networks in Eighteenth-Century Paris (Cambridge, MA: Belknap Press, 2010); and, most recently, Censors at Work: How States Shaped Literature (New York: W.W. Norton \& Company, 2014).

8 Joseph Harris, Inventing the Spectator: Subjectivity and the Theatrical Experience in Early Modern France (Oxford: Oxford University Press, 2014), p. 7. 
as Georg Fuchs, Vsevolod Meyerhold, and, of course, Berthold Brecht and Antonin Artaud. ${ }^{9}$

In this essay, written from a less teleological perspective in which there is no real need to critique this experience as being inherently dull, bad, or politically weak, I will attempt to show that the 'securing' or 'rescuing' of theatre was appropriated by proponents of the emotional (and therefore artistic) values of performance and taken from the hands of both wary ecclesiastics and utilitarian pedagogues. This process of redefinition, which occurred during the first few decades of the eighteenth century in France, ushered in a new conception - a new definition - of early modern theatre comparable to more recent conceptions of the dramatic arts that define theatre as a holistic, multisensorial, and lived experience rather than as a particularly prestigious example of poetry. This is one example of how I believe that 'theatre history can be understood and described as cultural history'.10 Unearthing this cultural history - the history of anthropological, experience-focused theories of theatrical performance in seventeenth- and eighteenth-century France-requires the analysis of a specific culture and how it negotiated a unique triangle of meaning that is inherent to the stage: that of perception, body, and language.

2

\section{Local Specificities: Theatre and Anti-Theatre in Seventeenth-Century France}

The rise of theatre as a social event in seventeenth- and eighteenth-century France catalysed a rich period of theorising and production leading to what Voltaire and others called an epoch of theatromania. The popularity of dramatic literature and theatre attendance encouraged a variety of different personalities-from philosophers to government officials to ecclesiastics-to weigh in on the merits or drawbacks of theatre as an institution, an experience, and an art. Because it involves actual human bodies and the audio-visual transmission of sensory material, moreover, the theatre was a natural venue for discussing essential questions in early modern psychology, such as: Is pleasure anatomical or metaphysical? How is cognition affected by visual elements of the stage? Are actors really emotional, or do they just appear emotional? Do emotions help or hinder learning?

$10 \quad$ Fischer-Lichte, p. 9. 
One place to start this line of inquiry is in the second half of the seventeenth century, which is often deemed the golden era of French dramatic output (Pierre Corneille (1606-1684), Jean Racine (1639-1699), Jean Rotrou (1609-1650), and Molière (1622-1673)) and theorisation (François Hédelin, abbé d'Aubignac (1604-1676), Charles de Saint-Évremond (1613-1703), Hippolyte-Jules Pilet de La Mesnardière (1610-1663), and, again, Corneille and Racine)). Contrary to powerful critics of the Académie française, like Georges de Scudéry (1601-1667) or Jean Chapelain (1595-1674), Corneille believed - to different degrees at different moments in his life-in formal invention, in mixing registers, and even in the emotional pleasure that spectators and readers enjoy during and after their experiences with drama. In his Trois discours sur le poème dramatique (166o), for example, Corneille asserts that pleasure-and, in particular, the affective creation of pleasure in the soul of the spectator-is the chief goal of tragic dramatists. At the beginning of his 'Premier discours', however, Corneille makes an important qualification regarding the type of pleasure one should feel with tragedy. Commenting on Aristotle, he writes:

Bien que selon Aristote le seul but de la Poésie Dramatique soit de plaire aux Spectateurs, et que la plupart de ces Poèmes leur aient plu, je veux bien avouer toutefois que beaucoup d'entre eux n'ont pas atteint le but de l'Art. Il ne faut pas prétendre, dit ce Philosophe, que ce genre de Poésie nous donne toute sorte de plaisir, mais seulement celui qui lui est propre; et pour trouver ce plaisir qui lui est propre, et le donner aux Spectateurs, il faut suivre les Préceptes de l'Art, et leur plaire selon ses Règles. ${ }^{11}$

Even though the only goal of Dramatic Poetry is to please Spectators and that the majority of Plays pleased them, I would like however to argue that many of them never attained the goal of the Art. One must not try to argue, said this Philosopher, that this type of Art gives us any sort of pleasure, but only its own type; and in order to find this type, and to give it to Spectators, one must follow the Principles of Art, and give pleasure to them according to its Rules.

Corneille's two-headed praise of both pleasure and universal rules is a famous cornerstone of French classical doctrine - a doctrine that has emerged, thanks to the recent works of Georges Forestier and John Lyons, as a fertile network

11 Pierre de Corneille, 'Premier discours', Trois discours sur le poème dramatique (1660) (Paris: Flammarion, 1999), p. 63. 
of competing tensions instead of a set of intransigent, universal rules. ${ }^{12}$ But by establishing terror and pity as the only emotions worthy of representation and by prescribing a universal path for emotions that runs from overwhelming feeling to mystical purgation, French classical theorists like Corneille limited emotional diversity and intensity by excluding a full gamut of emotions and valences that dramatists (including Corneille himself) actually employedemotions like romantic love, friendship, maternal or paternal sentiment, and patriotism.

Many classical theorists attached the moral effects of drama to its emotional effects in an effort to follow Aristotle à la letter. This attachment may also have been a way to justify the proliferation of theatre as an institution during the seventeenth century, or even an attempt to explain the manifestation of a certain nonchalance vis-à-vis the importance of performance within a critical equation of aesthetic judgment. The narrow range of emotions emphasised by these theorists, when compared to the wide variety of emotional situations in plays at the time, left dramatic literature and theatrical performance open to a series of attacks on both emotional and moral grounds. The most prolific and complex of these attacks came from the French ecclesiastics, Pierre Nicole (1625-1695) and Jacques-Bénigne Bossuet (1627-1704).

Nicole, the famous Jansenist master of the Port-Royal abbey, was cognisant of the fact that plays did not merely stage serious emotions like terror and pity, so he mounted a logical and structured assault against the theatre in his Traité de la Comédie (1667). Nicole's attack was comprehensive: he sought to unearth how theatre negatively affected individuals, interpersonal relationships, and even society as a whole. Just as comprehensive as the intellectual scope of his project were the formal and conceptual aspects of theatre targeted by Nicole in his treatise. For example, Nicole writes of acting that

12 Georges Forestier, Passions tragiques et règles classiques (Paris: Presses universitaires de France, 2003); John D. Lyons, Kingdom of Disorder: The Theory of Tragedy in Classical France (West Lafayette: Purdue University Press, 1999). It is important to note that dramatic 'rulemaking', a quintessential part of classical theory, was part and parcel of a nascent psychological discourse in seventeenth-century France. As Harris points out in Inventing the Spectator, 'all these accounts suggest that dramatic theory can offer privileged insight into the supposedly universal nature of human psychology. In all these examples [of classical rulemaking], the rules are not the opposite of subjectivity; on the contrary, they underpin it. The rules are so deeply buried in our nature that we can become aware of their general precepts only through our individual responses' (9). 
C'est un métier qui a pour but le divertissement des autres; où des hommes et des femmes paroissent sur un théâtre pour y représenter des passions de haine, de colère, d'ambition, de vengeance, et principalement d'amour. Il faut qu'ils les expriment le plus naturellement et le plus vivement qu'il leur est possible et ils ne le sçauroient faire, s'ils ne les excitent en quelque sorte en eux-mêmes, et si leur âme ne prend tous les plis que l'on voit sur leur visage. Il faut donc que ceux qui représentent une passion d'amour en soient en quelque sorte touchez pendant qu'ils la représentent, et il ne faut pas s'imaginer que l'on puisse effacer de son esprit cette impression qu'on y a excitée volontairement, et qu'elle ne laisse pas en nous une grande disposition à cette même passion qu'on a bien voulu ressentir. ${ }^{13}$

The goal of this career is to amuse others; where men and women appear on a stage to perform the passions of hate, anger, ambition, revenge, and mostly love. They must express these passions the most naturally and the most vividly as they can, and they can only do this if they excite themselves in some way and if their souls accept all of the folds that one sees on their faces. Those who perform a passion of love must be somehow touched by it while they are performing, and we can never hope to erase this impression from our minds that was already voluntarily excited, and [we can never hope] that it [the impression] won't leave in us a powerful disposition to this same passion that we so very much wanted to feel.

In Nicole's detailed description of how actors prepare for and execute their roles on stage, a wide array of emotions are fully embodied by the actor and then transferred immediately to the spectator. The actor commits a sin, such as lust or envy, and then enchants spectators into committing sins themselves. The sin is then impossible to 'erase', becoming a repeatable, emotionally learned act even after the end of the performance. The behaviour or 'disposition' of spectators and actors is thus forever changed, for 'we can never hope' to rid ourselves of the nefarious, corporeal lesson gleaned from the audiovisual event. For Nicole, theatrical affect overpowers the mindful processes of the spectator or the actor; no remedy exists to counteract the emotions of performance.

13 Pierre Nicole, 'Traité de la Comédie', in Traité de la Comédie et autres pièces d'un procès du théâtre, ed. by Laurent Thirouin (Paris: Honoré Champion, 1998), p. 37 (chapter II). 
Later in the Traité, Nicole builds upon his theories of immediate impressionability and enduring consequences by employing food and poison metaphors to describe the effect of performance on spectators. ${ }^{14}$ In doing so, he removes or at least displaces Corneille's argument that emotions are first felt but then dissipate or are purged at the end of the show. According to Nicole, Corneille's take on the value of emotion is false because of how the dramatist conceptualises its source and path. Emotions in the theatre are, for Nicole, once again grounded in the body. For Corneille, emotional response is more ambiguous; at times controlled, at times transcendental, emotions are often rationally employed and deployed by a tactful dramatic author. In Nicole's Traité, however, lust, for example, is a transferrable somatic response, and the negative consequences of emotions felt during a theatrical performance overpower any authorial intent to control the calibration, duration, or trajectory of the emotion. Dramatic literature, as proponents of theatre suggest, may indeed have values as well as important emotions that are attached to-or that are catalysts of - those values. But, and this is a sticking point, dramatic literature is not theatre to religious opponents of the stage. The locus of theatre for them, just like for later proponents of a 'transformative power of theatre' centuries later, is predicated on the audio-visual event of spectator attention to embodied fictional and non-fictional events on stage.

According to religious antagonists of theatre, spectators feel and then learn from performances through an efficient yet hazardous theatrical pedagogy. Learning in the theatre is passed into the soul from the body as spectators take pleasure in the constant visual stimuli. This means that theatre lacks any moral value because the information never passes into the mind, traveling instead directly to the soul from the body - an entity with, of course, a low moral status in religious writings across denominations. Writing about this process, Nicole contends that

Ainsi la Comédie par sa nature même, est une école et un exercice de vice, puisque c'est un art où il faut nécessairement exciter en soi-même des passions vicieuses [...]. Ce qui rend le danger de la Comédie plus grand, est qu'elle éloigne tous les remèdes qui peuvent empescher la mauvaise impression qu'elle fait. Le cœur y est amolli par le plaisir. L'esprit y est tout occupé des objets extérieurs, et entièrement enyvré des folies qu'il y voit représenter, et par conséquent hors de l'estat de la vigilance chrestienne nécessaire pour éviter les tentations. ${ }^{15}$

14 See, for example, Nicole, p. 85 (chapter Xxx).

15 Nicole, p. 43 (chapter vI). 
In this way the theatre, by its own nature, is a school and an exercise in vice, since it's an art in which one must necessarily excite vicious passions in oneself $[\ldots]$. What makes the theatre even more dangerous is that it distances us from all of the possible remedies that could prevent the bad impressions that it makes. The heart is thus softened by pleasure. The mind is thus occupied by exterior objects and entirely intoxicated with the madness that it sees performed and, by consequence, outside the state of Christian vigilance [vigilance chrétienne] necessary to avoid temptations.

Nicole's argument against authorial power is radically different from Corneille's description of how dramatic authors ought to write good tragedies. For Corneille, emotions are planned by the author and then correctly executed (or not) by the actors on stage. These serious and noble emotions are then purged at the end of the theatrical experience during a moment of pleasure, lodged somewhere between intellectual clearing and emotional relief.

Conversely, Nicole reiterates a natural disconnect between authorial intent and the actual lived emotional experience of spectators during a performance: the author may intend, for example, to represent terror; the spectators, according to Nicole, might instead feel lust for the scantily clad characters on stage (a real or non-fictional response to dramatic fiction) or perhaps admiration for the evil character whose crime goes unpunished (an unintended or 'morally wrong' response to fiction). Theatrephobes like Nicole deny the existence of any purgative process - the cleansing process reserved for the Catholic church's own emotional moments like transubstantiation, benediction, or post-confessional grace, for instance (it being essential not to forget that theatre was in competition with the church for a place in the emotional lives of potential worshippers).

Informed by Cartesian mechanics and close readings of contemporary dramatic theories, Nicole's attack against the theatre on moral and emotional grounds was ultimately different than the host of other anti-theatrical diatribes dating back to antiquity. Given that the Jansenist ecclesiastic attacked state theatre at the height of its support by the crown, Nicole's Traité provoked several direct responses by prominent playwrights and theorists during the years immediately following the publication of certain chapters in 1664, a full edition in 1667, and a second edition in 1675. Racine (young Racine-not the serious and pious Racine who turned against the theatre later in life), for example, wrote a response to Nicole (who was his former classics and rhetoric teacher) in the Lettres provinciales that compares plays to church writings, arguing that even a pious theologian like Blaise Pascal 'introduces on the 
stage at times Dominicans, at times doctors, and always Jesuits' ('introduit sur la scène tantôt des jacobins, tantôt des docteurs, et toujours des jésuites'). ${ }^{16}$ Racine's defence of the theatre was bold from a poetical and polemical point of view: he gestures at the similarities between the writings of a moralist and the texts of dramatic authors. Racine goes on to say that he 'could say just as much about novels' ('pourr[ait] dire autant des romans'), ${ }^{17}$ once again brazenly connecting both traditions, but ultimately sidestepping Nicole's arguments about theatrical performance (and, mainly, his argument that the emotions of performance are not grounded in cognition and are thus not moral). Racine, like many seventeenth-century doctes, relegates (at least de facto) 'theatre' to dramatic scripts and universal poétiques.

Nicole's attack was as much against the experience of spectatorship as against the character compositions, situations, and plot twists of dramatic writing. Racine, for whatever reason (fear of retribution; inability to conceptualise the performance as part of an aesthetic system; desire to polemicise the event), did not want to respond to the 'experience' part of Nicole's argument. Two decades later, the Theatine priest Francesco Caffaro (1650?-1720) also favoured this 'poetic' and institutional approach by attempting to defend theatre by authoritative historical argument (e.g., church fathers such as St. Thomas and St. Cyprian were not totally against visual spectacles) and in sociological perspective (e.g., Caffaro writes that he knows plenty of upstanding people who attend theatre performances) ${ }^{18}$ Rather than persuading French fidèles of theatre's merits, however, Caffaro's Dissertation provoked the indignation of a host of religious writers. In the most famous response, the renowned bishop and orator Jacques-Bénigne Bossuet systematically dismantled every one of Caffaro's historical arguments and essentially condemned his theatregoing pals to hell in his masterful Maximes et réflexions sur la Comédie (1694) $\cdot{ }^{19}$ Bossuet picks up where Nicole left off, once again relegating the emotions felt during a performance to the unconscious and recategorising the various

16 Jean Racine, 'Seconde lettre en réplique aux deux précédentes [10 mai 1666]', in Lettres de Racine à l'Auteur des Hérésies imaginaires et des Deux visionnaires (1667), in OEuvres complètes de Jean Racine, vol. IV (Paris: Pinard, 1829), p. 67.

17 Racine, p. 68.

18 Francesco Caffaro, Lettre d'un théologien illustre par sa qualité et par son mérite, consulté par l'auteur pour savoir si la Comédie peut être permise, ou doit être absolument défendue (Paris: Jean Guignard, 1694), in L'Église et le théâtre, ed. by Ch. Urbain and E. Levesque (Paris: Grasset, 1930), pp. 67-119.

19 Maximes et réflexions sur la Comédie (1694), in CEuvres complètes de Bossuet (Paris: Louis Vivès, 1862); also reprinted in L'Église et le theatre, ed. by Urbain and Levesque, pp. 120-240. 
positive emotions deployed in drama into strict categories of concupiscence and greed. ${ }^{20}$

By the end of the century, the church was a main source of theorisation about the types of emotions felt during a theatre performance and the longterm repercussions of those emotional moments. Proponents of the stage were, for the most part, silent ${ }^{21}$ —or, if not, either continued to focus on the utility of theatre or employed the 'it's only harmless pleasure' argument. ${ }^{22}$ Religious supporters of theatre, like Caffaro, grounded their arguments in the historical justification of spectacle, running up against the matter-of-fact response from theatrephobes that the Stations of the Cross, for example, have little to do with Tartuffe. It is only this group-religious anti-theatrical writers-who seem to go to any lengths to describe the somatic and psychic mechanisms involved in the theatrical experience.

\section{3}

\section{Rescuing the Emotions of Theatrical Performance}

At the beginning of the eighteenth century, the theatrical experience was in theoretical crisis. While theatregoers continued to attend performances in droves, any positive effects of performance were absent, de-emphasised, or incorporated into utilitarian models in theoretical discourses of the time. In order for proponents of the theatrical experience to be able to 'rescue' performance from the hands of anti-theatrical zealots, they would need a new set of arguments-arguments that bolstered the positive role of the emotions in learning (as opposed to the claim that emotions overwhelm more mindful processes like learning), as well as arguments that increasingly focused the theatrical experience on spectator attention to a fictional event (rather than on a real

20 On the psychology of spectatorship Bossuet writes that 'pendant qu'on est enchanté par la douceur de la mélodie ou étourdi par le merveilleux du spectacle, ces sentiments s'insinuent sans qu'on y pense et plaisent sans être aperçus' ('while we are enchanted by the softness of the melody or overwhelmed by the magic of the spectacle, these feelings insinuate themselves without our knowledge and give us pleasure without being noticed'): CEuvres complètes de Bossuet, XVII, p. 21.

21 Many initial supporters of (or at least those who did not immediately condemn) Caffaro's defence of the theatre were reluctant to speak out after he was threatened with excommunication in 1694. For further details, see Henry Phillips, The Theatre and its Critics in Seventeenth-Century France (Oxford: Oxford University Press, 1980).

22 Examples are numerous: see, for instance, the overall gist of Molière's La Critique de l'École des femmes (1663) or the more explicit pleasure arguments in Racine's preface to Bérénice (1670). 
danger). This 'refocusing effort', an example of which I will show here, ushered in a positive, anthropological discourse related to theatrical performance-a pro-dramatic theory of the stage that would come to dominate theatrical theories for decades and even centuries. ${ }^{23}$

The first quarter of the eighteenth century was witness to a fundamental change in the theory of theatrical emotions. In 1719, for example, Jean-Baptiste (the abbé) Dubos published the Réfléxions critiques sur la poésie et sur la peinture, in which he conceptualises the emotions of theatrical performance. About the type of emotion experienced by a spectator, Dubos writes:

Les Peintres \& les Poëtes excitent en nous ces passions artificielles, en présentant les imitations des objets capables d'exciter en nous des passions véritables. Comme l'impression que ces imitations font sur nous est du même genre que l'impression que l'objet imité par le Peintre ou par le Poëte ferait sur nous; comme l'impression que l'imitation fait n'est différente de l'impression que l'objet imité feroit, qu'en ce qu'elle est moins forte, elle doit exciter dans notre âme une passion qui ressemble à celle que l'objet imité y auroit pû exciter. La copie de l'objet doit, pour ainsi dire, exciter en nous une copie de la passion que l'objet y auroit excitée. ${ }^{24}$

Painters and poets excite these artificial passions by presenting imitations of objects capable of exciting true passions in us. Because the impression that these imitations make on us is of the same nature as the object's impression, imitated by the painter or the poet, would be on us; because the impression made by the imitation is only different than the imitated object's impression in that it is weaker, it must therefore excite in our mind a passion that resembles that which the imitated object could have excited. The copy of the object must thus excite in us a copy of the passion that the object would have excited.

23 While the scope of this article is introductory, examples of this positive, anthropological theory of the stage which I analyse in my larger project include the tragic works of Houdar de La Mothe, Marivaux's theoretical writings on theatre, Voltaire's 'emotional' tragedy of the 1730s, the comédie larmoyante, and Diderot's drame. The conclusion of this essay briefly sketches this project. For more information, see Logan J. Connors, 'Interpretations', in The Cultural History of Theatre: The Enlightenment, ed. by Mechele Leon (London: Bloomsbury, 2017).

24 Jean Baptiste Dubos, Réflexions critiques sur la poésie et sur la peinture I., 3 (1719) (Paris: Pissot, 1770), p. 27. 
Dubos adds layers and phases to what he conceptualises as a cognitive act of spectating; the immediate, physical, and even overwhelming aspects of emotion intimated by Corneille and other classical theorists, and then explained quite explicitly by church officials are subdued and sequenced by Dubos into a mindful event that includes both sensory perception and information processing. It is important to note that Dubos is not trying to 'rationalise' or downplay the emotions felt by spectators during a performance; these emotions are not the same emotions that characterise the everyday lives of spectators, but he is quick to point out that they certainly feel like 'real' emotions. Yet spectators have made the concerted effort to attend the play and their expectations are framed in a specific way. The emotions felt in response to theatre are thus categorically different from those experienced in everyday life, and it is therefore safe to take pleasure in the performance-even if this pleasure feels the same as pleasure induced by another, non-theatrical source. To use Nicole's lexicon, because these emotions do not affect spectators 'in the soul' ('réellement'), their 'vigilance chrétienne' remains unscathed, coexisting with any 'theatrical self' during the performance.

Continuing to describe this emotional process, Dubos writes:

Nous jouissons de notre émotion, sans être alarmés par la crainte qu'elle dure trop long-tems. C'est, sans nous attrister réellement, que la pièce de Racine [Phèdre] fait couler des larmes de nos yeux: l'affliction n'est, pour ainsi dire, que sur la superficie de notre cœur, \& nous sentons bien que nos pleurs finiront avec la représentation de la fiction ingénieuse qui les fait couler. ${ }^{25}$

We enjoy our emotion without being alarmed by the terror that it might last too long. It's without really saddening us that Racine's play [Phèdre] puts tears in our eyes: the affliction, one might say, is only on the surface of our heart and we feel without difficulty that our tears will end with the performance of the ingenious fiction that caused them to flow.

It is possible that Dubos's theory of the emotions is a careful reflection on the emotions of theatrical performance - an attempt to parse and map the emotions on the 'surface' of the heart, or what we might conceptualise now as a junction between mindful reflection and corporeal affect. Or perhaps Dubos's theory was rhetorical sleight of hand to remove discussions of theatre and pleasure from the church's purview and to justify the survival and proliferation

25 Dubos, pp. 30-31. 
of the dramatic arts during the turmoil of the Regency-a specific political and cultural 'post-absolutist regime' of relative openness in the wake of Louis XIV's death. ${ }^{26}$ Authorial intent does not matter as much as the effects of the Réflexions - a text that was published many times throughout the eighteenth century and was later quoted by a host of dramatic authors and critics, including Rousseau, Diderot, Batteux, and Voltaire.

With his Réflexions critiques, Dubos refocused dramatic theory onto the theatrical performance - and, particularly, onto the emotional experiences of spectators-by conceptualising emotion as a critical criterion for judging the value of drama. This feeling, located on the 'surface of our heart', differed from anti-theatrical notions of 'real' affect as well as from 'cathartic' or 'purgative' narratives of how the emotions operate in theatre. Most importantly, Dubos adds what we might call an 'emotional safety net' to the activity of spectating. Critics could now evaluate a play using relational criteria enjoyed during the spectator-critic's experience with the event because this experience was mindful and emotional. Pleasure is thus a knowledge building process, rather than a confusing state of ecstasy or an overpowering feeling of excitement. Although it would go beyond the scope of this short essay, it is important to note in passing that important correlations exist between Dubos's emotional 'rescuing act' and the same type of 'reduction' or 'softening' of the passions into 'useful interests' in the works of Adam Smith, Bernard de Mandeville, Montesquieu, David Hume, and other philosophers at the time. ${ }^{27}$

In the dramatic field, shortly after the publication of Les Réflexions, several prominent writers employed an aesthetic that they termed le pathétique or l'effet or l'intérêt sentimental. This new aesthetic emerged as a more holistic, more diverse, and even more accurate means by which to treat the emotions. Where there was once an attempt to depict a universally constructed (or what was thought to be a universally constructed) emotion like terror, there was now a new emphasis on real spectator affect, grounding theatre in dramatic subjects that were thought to resonate more with spectators. Authors of comédies

26 Jay Caplan describes the period of 'post-absolutist culture' after Louis XIv's death as marked by 'the passing of absolutism as a cultural order, and to the emergence of new forms — of value, subjectivity, and legitimacy — that would survive the political death of absolutism'. See In the King's Wake: Post-Absolutist Culture in France (Chicago: University of Chicago Press, 1999), p. 2.

27 For a masterful essay on the differences between passions and 'interests' during the first half of the eighteenth century, see Albert O. Hirschman, The Passions and the Interests: Political Arguments for Capitalism before its Triumph (1977) (Princeton: Princeton University Press, 1997). 
larmoyantes, drames, and other 'new genres' demonstrated heightened concern for the audio-visual event of performance. Many productions conceptualised the emotions as relational, based on a more complex ideal subject rather than on a unified docte from antiquity or on a religious teleology of sin avoidance. Dubos's inclusive and safe take on the emotions gave dramatic authors the theoretical undergirding to justify veritable psychological experiments with their plays-experiments in which new types of characters negotiated new emotional situations like nostalgia, patriotism, and friendship. ${ }^{28}$

One example of the desire to bind emotionality with complex thought processes in the wake of Dubos's text is in Houdar de La Motte's (1672-1731) Inès de Castro of 1723. La Motte's tragedy was the first to place a child on stage at the Comédie-Française, drawing in the emotional attention of both the characters and the audience. At the conclusion of the play, the King decides to end his unjust course of action preventing marriage between his son, the Prince, and the lowborn Inès, after seeing their children for the first time - an ethical decision triggered by a 'non-linguistic' emotional event. ${ }^{29}$ Although the present essay cannot give justice to this dramaturgical-emotional regime change, other examples include Marivaux's experiments on the immediacy and function of love in society (e.g., Le Triomphe de l'Amour and La Surprise de l'Amour) as well as works by Voltaire and Nivelle de La Chaussée-tragedies and comedies that represent the complexities of specific emotional valences and intensities through, among other strategies, increasingly identificatory and emotional plots deployed with visual considerations that draw attention to the stage.

My essay is part of a larger investigation that will trace the history of the 'theatrical event' in France from the religious critiques of the seventeenth century to the anthropological, pro-dramatic criticism of the Enlightenment. In this short study of Nicole and Dubos as well as in the larger project, my goal is to address, at least in part, what the historian William Reddy sees as a difficulty when literary scholars analyse the representation of emotions from before the advent of modern psychology. Reddy writes that 'they [literary historians] tend to regard ideas about emotions from the past as interesting, even fascinating, configurations to be understood as part of their own time. They have not asked themselves what relation such past ideas have to the "reality" of emotions. ${ }^{30}$

28 One instance of the desire to experiment with theatre in terms of the emotional and pedagogical values of performance is elucidated in Marivaux's Réflexions sur l'esprit humain à l'occasion de Corneille et de Racine (1744), in Journaux et œvres diverses, ed. by F. Deloffre and M. Gilot (Paris: Garnier, 1969), pp. 465-77.

29 Antoine Houdar de La Motte, Inès de Castro, tragédie (Paris: Chez Dupuis, 1723).

3o Reddy, p. ix. 
The 'reality' of emotions is certainly a tricky construction - a likely reason why Reddy puts the term in scare quotes. Nevertheless, is it not possible that theatre, with its concern for things and 'non-things', is an experience to which we can turn to find moments when specific 'cultures', like that of early modern France, began to conceptualise their limits without recourse to religion and to discuss processes in which something like nature or reality play a role? Early modern writers, including Nicole and Dubos, reflected on the innateness of visual processes as well as on the fact that this apparent innateness might be part of a culturalisation (better for Dubos; worse for Nicole) involved in attending the theatre. These enemies and friends of the stage-like psychologists, anthropologists, and philosophers today who try to tease out the 'commerce' (to use Locke's term) between nature and nurture-began to recognise the complexity of our psyche and to observe that it includes, like a theatre performance, both ephemeral and deliberate (staged) processes. Eighteenth-century theatrical theories, like recent research into emotion and learning, ${ }^{31}$ gesture to the power of emotions despite their deeply ambiguous character and our very best efforts to control, subdue, or divert them through reason, 'Christian vigilance', and universal poetic systems.

31 See, for example, Shari Stenberg, 'Teaching and (Re)Learning the Rhetoric of Emotion', in Pedagogy: Critical Approaches to Teaching Literature, Language, Composition, and Culture, vol. XI. 2 (2011), pp. 349-69; Raymond A. Mar and Keith Oatley, 'The Function of Fiction is the Abstraction and Simulation of Social Experience', Perspectives on Psychological Science, 3 (2008), pp. 173-92; K. Oatley and S. Nundy, 'Rethinking the Role of Emotions in Education', in The Handbook of Education and Human Development: New Models of Learning, Teaching and Schooling (Cambridge, MA: Blackwell, 1996), pp. 257-74. 